\title{
Empirical Analysis of Monetary and Fiscal Policies and Balance of Trade Dynamics in Nigeria (1981- 2017)
}

\author{
Aderoju Bolanle Rahmon ${ }^{1}$ and Odunsi-Oyewole Oluwatosin Adefunke ${ }^{2}$ \\ 1. Department of Economics, School of Arts and Social Sciences, The College of Education, Lanlate, P. M. B. \\ 001, Oyo State, Nigeria \\ 2. Department of Economics, School of Arts and Social Sciences, The College of Education, Lanlate, P. M. B.
} 001, Oyo State, Nigeria.

\begin{abstract}
This paper empirically investigated the relationships among money supply, government revenue, government expenditure, domestic debt, external debt, inflation rate, exchange rate and balance of trade in Nigeria based on time series data which spanned between 1981 and 2017. The data were sourced from Central Bank of Nigeria Statistical Bulletin publications of various issues and National Bureau of Statistics. The data were tested for stationarity using Augumented Dickey Fuller unit root test and Phillips-Perron unit root test while the cointegration test was conducted using Johansen's methodology. Ordinary Least Square (OLS) estimating technique was used for the empirical analysis. The findings revealed that both the explanatory variables and the dependent variable have long run equilibrium relationship. The results further demonstrated that government revenue (GREV), government expenditure (GEXP), exchange rate (EXGR) and inflation rate (INFR) have statistically significant positive relationships with balance of trade (BOT) while money supply (MS), domestic debt (DDEBT) and external debt (EDEBT) exert statistically significant negative impact on balance of trade (BOT) in Nigeria. Based on the results, government at all levels should ensure implementation of monetary and fiscal policies' instruments aimed at promoting favorable investment atmosphere through appropriate stabilization of interest rates, exchange rates and inflation rates in order to galvanize economic growth, economic stability, economic sustainability and favorable balance of trade; there should be promotion of exportation of Nigerian products by the government especially non-oil products in order to bring more foreign exchange earning into the country, boost productive activities and improve the balance of trade position of the country. In addition, government should ensure that loans borrowed from domestic and external sources are judiciously expended on productive activities in order to positively influence balance of trade; and there should be imposition of ban on importation of products that can be manufactured domestically so as to expand productive capacity of indigenous industries and ensure favorable balance of trade. Finally, different tiers of government should invest massively on critical infrastructure in the economy to boost local investment in productive activities, thus galvanizing balance of trade.
\end{abstract}

Keywords: Monetary Policy, Fiscal Policy, Balance of Trade, Unit Root Test, Co-integration Test, Ordinary Least Squares, Nigeria

DOI: $10.7176 / \mathrm{JPID} / 50-07$

Publication date:June $30^{\text {th }} 2019$

\section{Introduction}

The governments in most advanced and developing countries usually employ fiscal policy and monetary policy instruments with the overall objective of maximizing the welfare of their citizens. Fiscal policy is concerned with the optimal use of taxation and government spending to control and adjust the aggregate demand in an economy. Monetary policy, on the other hand, refers to the utilization of central bank's monetary weapons to control and regulate the availability of credit in the economy in order to achieve the objectives of price stability, increased gross domestic product growth rate, reduction in inflation rate, decline in unemployment rate, improvements in the balance of payments, accumulation of financial savings and external reserves as well as stability in Naira exchange rate and this control can be exerted through money supply, exchange rate, interest rate and inflation rate. Both fiscal and monetary policies are utilized by various governments all over the world to achieve macroeconomic objectives of sustainable economic growth, achievement of full employment of resources, price stability, income redistribution and maintenance of balance of payments equilibrium. Balance of trade is a major component of the balance of payment which shows the difference between a country's exports and imports of goods alone, that is, visible items. Balance of trade of any given economy is influenced by numerous factors which include factor endowments, trade policies, exchange rates, inflation rates, foreign currency reserves, level of productivity and domestic demand. The net effect of balance of trade is either 
positive, negative or zero. A nation is said to have a favorable or surplus balance of trade if its exports value are greater than imports whereas an unfavorable or deficit balance of trade occurs when the values of imports are higher than exports. Investors and policymakers are increasingly using balance of trade data to determine the health of the economy and its relationship with the rest of the world. Countries generally try to formulate trade policies that facilitate achievement of a favorable balance of trade. They prefer to sell more goods and earn higher income, thus improving the standard of living of their citizens.

In Nigeria, the figure for balance of trade has been fluctuating over the years. According to Central Bank of Nigeria Statistical Bulletin (2017), the country had a deficit balance of trade amounting to \#1.8 billion in 1981. The figures for favorable balance of trade were \#4.7 billion and \#64.2 in 1985 and 1990 respectively. The figure skyrocketed to \#195.5 billion in 1995. The country experienced a deficit balance of trade in 1998 to the tune of \#85.6 billion. In 2000, there was a transformation to a surplus balance of trade totaling \#960.7 billion. In 2005 , balance of trade figure rose to \#4445.7 billion and later declined to \#3847.5 in 2010. Owing to significant reduction in the international price of crude oil which constitutes the major export product of the economy, the country witnessed great deficit in her balance of trade to the tune of \#2230.9 billion and \#644.8 billion in 2015 and 2016 respectively. In 2017, there was a shift from deficit to surplus amounting to \#3183.3 billion. The foregoing scenario clearly underscores the fact that balance of trade figures have been fluctuating over the years. But the impact of monetary and fiscal policies' instruments on balance of trade dynamics are yet to be investigated.

It should be acknowledged that several studies have been conducted on the impact of monetary policy variables such as exchange rate, interest rate and inflation rate on the balance of payment in Nigeria. Other studies focused on the nexus between fiscal policy measures and balance of payment. Only few studies examined the effectiveness of monetary and fiscal policy instruments in promoting sustainable economic growth in the economy. To the best of our knowledge, this is the first empirical study that analyzes the impact of monetary and fiscal policy instruments on balance of trade dynamics in Nigeria. This study intends to fill the lacuna in the literature by providing answers to the following questions: what impact do monetary policy variables like money supply, inflation rate and exchange rate have on balance of trade dynamics in Nigeria? Do fiscal policy measures exert statistically significant positive or negative influence on balance of trade dynamics in Nigeria? Which of the two policies' instruments (monetary or fiscal) are more effective in controlling or stabilizing balance of trade dynamics in Nigeria

\section{Objectives of the Study}

The general objective of the study is to empirically investigate the impact of monetary and fiscal policies on balance of trade dynamics in Nigeria over the period 1981 and 2017. The specific objectives are:

-To examine the relationship between monetary policy variables (money supply, exchange rate and inflation rate ) and balance of trade dynamics in Nigeria.

-To analyze the nexus between fiscal policy variables (government revenue, government expenditure, domestic debt and external debt) and balance of trade dynamics in Nigeria over the studied period.

-To recommend policy prescriptions based on the estimated result.

\section{Study Hypotheses}

The hypotheses to be verified by this study are stated in null and alternative forms below:

1. $\mathrm{H}_{0}$ : Monetary policy variables (money supply, exchange rate and inflation rate) have no statistically significant positive relationship with balance of trade in Nigeria.

$\mathrm{H}_{1}$ : Monetary policy variables such as money supply, exchange rate and inflation rate have statistically significant positive relationship with balance of trade in Nigeria.

2. $\mathrm{H}_{0}$ : Fiscal policy instruments such as government revenue, government expenditure, domestic debt and external debt have no statistically significant positive connection with balance of trade in Nigeria.

$\mathrm{H}_{1}$ : Fiscal policy instruments such as government revenue, government expenditure, domestic debt and external debt have statistically significant positive connection with balance of trade in Nigeria. 


\section{Research Questions}

1. What impact do monetary policy instruments or variables have on balance of trade dynamics in Nigeria?

2. Do fiscal policy instruments or variables exert significant positive or negative connection with balance of trade dynamics in Nigeria?

3. Which of the two policies is more effective in controlling or stabilizing balance of trade dynamics in Nigeria

\section{Review of Related Literature}

Monetary policy and fiscal policy are techniques of economic management employed by nations all over the world with the aim of achieving sustainable economic growth and development. The utilization of these techniques by different countries for formal articulation of how money affects economic aggregates dates back to the time of Adam Smith. Since the expositions of the role of monetary policy and fiscal policy in influencing macroeconomic objectives like promotion of rapid economic growth, achievement of price stability, maintenance of equilibrium balance of payment, income redistribution, achievement of full employment of resources and others, monetary and fiscal authorities have been using these policies to achieve economic growth and development of their economies.

Several empirical studies have been conducted on the impact of exchange rate, interest rate and inflation rate on the balance of payments in Nigeria. Other studies concentrated on the effectiveness of monetary and fiscal policy instruments in stabilizing output growth in Nigeria. A few others focused on the nexus between fiscal policy variables and balance of payment in Nigeria. It should be pointed out that the literature on the impact of monetary and fiscal policies on balance of trade dynamics in Nigeria are very scanty. Adewale (2018) empirically examined the effectiveness of monetary and fiscal policy instruments in stabilizing Nigerian economy over the period 1981 and 2015. The data were sourced from Central Bank of Nigeria, National Bureau of Statistics and World Development Index (WDI). The data were tested for stationarity using Augumented Dickey Fuller (ADF) unit root test, while the co-integration test was conducted using Johansen's methodology. Error Correction Model (ECM) was employed for the empirical analysis. The results show that there is long run equilibrium relationship between monetary and fiscal policy instruments and economic growth in Nigeria. ECM has the expected negative sign and is between the accepted region of less than unity. This was confirmed by the positive relationship between money supply, government expenditure and revenue while interest rate and budget deficit have negative relationship with economic growth. The study recommended that there should be effective use of money supply and government expenditure as key instruments of monetary and fiscal policy in Nigeria in order to improve the economy.

Imoughele and Ismaila (2015) examined the monetary policy and balance of payments stability in Nigeria using time series data which spanned between 1986 and 2013. The effects of stochastic shocks of each of the endogenous variables are explored using error correction model. The co-integration test conducted showed that long run relationship exists among the monetary policy variables and balance of payments. Empirical findings revealed that monetary policy variables of exchange rate, broad money supply and credit to the private sectors are the major monetary factors that determine balance of payments in Nigeria. The study concluded that monetary policies and implementation capacity is important in the Nigerian economy because it is very special for determining the provision of interest rate to private sector which produce for export which will have a spillover effect on balance of payments and economic growth. Adegoriola and Siyan (2015) investigated the relative impact of money supply and government expenditure on economic growth in Nigeria. The beta coefficients techniques and Two Stage Least Square were employed to analyze the data. Three different models were used namely monetary model, fiscal model and monetary and fiscal model. The empirical result revealed that broad money supply is more effective among the two monetary policy instruments (broad money supply and interest rate). While in the fiscal model, government expenditure is more potent than any of the other two fiscal policy instruments (tax revenue and budget deficit). On the third model (monetary and fiscal), the result showed that government expenditure is relatively more effective compared with money supply on economic activities. They found out that the impact of government expenditure as a fiscal policy instrument is greater, more reliable and faster in stabilizing the Nigerian economy than money supply as a monetary policy instrument. They 
therefore advised that both policy instruments can be mixed to bring about economic growth and stability for Nigeria.

Falade and Folorunso (2015) examined the relative effectiveness of fiscal and monetary policy instruments on economic growth sustainability in Nigeria. Error correction methodology was employed whereby the time series properties of fiscal and monetary variables were first examined using Augumented Dickey Fuller and Phillip Perron unit root tests, followed by Johansen co-integration test among the series using annual data for the period 1970 to 2013. Empirical findings revealed that there is a long run relationship among fiscal and monetary variables and economic growth. The study found that the current level of exchange rate and its immediate past level, domestic interest rate, current level of government revenue and current level of money supply are the appropriate policy instruments mix in promoting economic growth both in the short and long run. The paper concluded that fiscal and monetary instruments are still complementary. Ajayi (2015) examined the determinants of balance $\mathrm{f}$ payments in Nigeria between 1970 to 2010. The study employed co-integration method to assess the long run impact of macroeconomic variables and found a negative significant relationship between monetary policy instruments and balance of payments. The study concluded that a larger exchange and a lesser monetary policy rate will raise the balance of payments of the Nigerian economy.

Havi and Enu (2014) conducted a study on the relative importance of monetary and fiscal policy on economic growth in Ghana and to determine which of these two policies is more powerful in promoting economic growth in Ghana. The study utilized time series data from 1980 to 2012 and Ordinary Least Squares estimation technique. They used three multiple regressions and showed that monetary policy impacts is potent in Ghanaian economy. Comparing the impact of both policies on Ghana's economy, the study revealed that monetary policy is more effective in promoting economic growth in Ghana than fiscal policy. The study recommended that monetary policies implemented by the Bank of Ghana should promote favorable investment atmosphere through appropriate stabilization of interest rates, lending rates, inflationary rates and exchange rates to promote and ensure economic growth, economic stability, economic sustainability and economic development in Ghana. Ogar et al. (2014) empirically investigated the effect of fiscal and monetary policy on the economic growth of Nigeria for the period 1986 to 2010e. The study employed the ordinary least squares method of statistical analysis. Two models were developed and analyzed for the study. Model 1 is the fiscal model while model II is the monetary model. It was found out that government revenue had a positive impact and statistical significant on gross domestic product. Government expenditure was also positively significant on the growth of Nigeria economy. The second model shows that money supply and exchange rate had positive and significant impacts on the performance of the Nigeria economy. Empirical finding also revealed that inflation had a positive impact but there was no significant relationship between inflation and gross domestic product. The paper recommends that government should increase the number of fiscal policy instruments over and above the ones currently in use.

Tijani (2013) empirically analyzed balance of payment adjustment mechanism using monetary channel in Nigeria from 1970 to 2010. The regression analysis found a positive relationship between the BOP and domestic credit, exchange rate and balance of trade while inflation rate and gross domestic product have a negative effect and concluded that monetary measures contribute immensely to the position of BOP, cause disturbances and serve as adjustment mechanism to bring BOP to equilibrium depending on its application and policy mix by monetary authority. Imosi et al. (2013) examined the efficacy of monetary policy in achieving balance of payments stability in Nigeria from 1980 to 2010 using an ordinary east squares technique of multiple regressions. The estimated result shows a positive relationship between the BOP and the monetary variables of money supply, exchange rate and interest rate. Specifically, money supply and interest rate had significant relationship with BOP whereas exchange rate was not statistically significant. The authors concluded that the government should promote the exportation of Nigerian products especially the non-oil products, as this will bring in more foreign exchange earning into the country, boost productive activities and improve the balance of payment position of the country. Danjuma (2013) determined whether excess money supply has played a significant role in the disequilibrium of the balance of payment in Nigeria during the period 1986 to 2010. Using Johansen co-integration test, vector error correction mechanism and the impulse response function and 
variance decomposition. The results showed that balance of payment in Nigeria is not a purely monetary phenomenon and the monetary authority in the country should seriously monitor budget deficit because this can also cause domestic credit increase.

Chigbmu and Njokwu (2013) examined the impact of monetary and fiscal policies on Nigerian economic growth over the period 1990 to 2010. Vector Autoregressive model and graph were some of the econometric techniques used for data estimation. Phillip-Perron test statistic revealed that the time series properties of the variables attained stationarity at first order. The variables were co-integrated at most 1 with at least 2 co-integrating equations. The variables used include minimum rediscount rate, cooperate income tax, interest rate, liquidity rate, federal budget and gross domestic product. Empirical findings revealed that federal budget is not statistically significant $t$ gross domestic product. However, interest rate and liquidity rate impacted negatively on the GDP but minimum rediscount rate, cooperate income tax and federal budget affect the GDP positively. The reaction of monetary and fiscal policies measures on the level of economic growth in Nigeria was found to be unstable over the years which indicated no long run relationship. The study further revealed that fiscal policy measures are more effective in stimulating economic growth in Nigeria. The study recommended that there should be effective strategic policies that enhance better fiscal policy implementation in Nigeria that will in the long run contribute to the national economic growth and also more robust and viable monetary policy measures should be made to achieve sound economic growth.

Kareem et al. (2013) analyzed the impact of Nigeria democracy on fiscal and monetary policies. The study adopted descriptive statistics, regression and correlation analysis on fiscal and monetary variables used (inflation, interest rate, narrow money, broad money and government recurrent and capital expenditure. Empirical findings revealed that there has been fluctuation in the trend of policy variables in Nigeria considered with reference to the stable democracy in Nigeria (1999-2008). The results also show that $96.3 \%$ of the variation (model 1) has been explained by the explanatory variables, $98.1 \%$ of the variation in dependent variable (model 2) has been explained by the explanatory variables, $99.4 \%$ of the total variation in dependent variable has been explained by the explanatory variables (model 3 ) and $85.7 \%$ of the total variation in the dependent variable (model 4) has been explained by the explanatory variables. The results further showed that broad money and recurrent expenditure have positive relationship with real gross domestic product (RGDP). The correlation results showed that narrow money, broad money and government recurrent expenditure are significant at $1 \%$ probability level while government capital expenditure is significant at 5\% probability level with inflation and interest rate having no significant relationship and negatively related with RGDP. The study concluded that narrow money, broad money, government recurrent expenditure and capital expenditure are significant variables that affect economic growth in Nigeria. Boateng and Ayentimi (2013) examined monetary approach to balance of payment in Ghana using annual data set that covered 1980 to 2010 . The ordinary least squares method was used for the study. Empirical results showed that the balance of payments in Ghana is not wholly a monetary phenomenon and found that monetary variables of domestic credit, inflation and interest rate have a significant impact on balance of payment proxy by net foreign assets.

Iyeli et al. (2012) conducted an econometric investigation on the relative effectiveness of monetary and fiscal policies on economic stabilization in Nigeria. The study focused on the relative effectiveness of broad money supply and government fiscal deficits with respect to their influences on economic activity represented by the gross domestic product. Error correction model was used with annual time series data for the period 1970 to 2001. The findings of the study revealed that the contribution of broad money supply to the inflationary cycle in Nigeria is weak. The effects of money supply factors on inflation in Nigeria appear dominant. While the role of fiscal deficit is pervasive. The study also confirmed that the role of fiscal policy (especially fiscal deficits) although positive, is negligible and in some instances statistically insignificant in influencing cyclical inflation rate in Nigeria within the period under review. It concludes that the effect of monetary policy on output growth has an edge over fiscal policy variable as a measure of output stabilization. Anna (2012) examined the relative effectiveness of monetary and fiscal policies on economic activity in Zimbabwe over the period 1981 and 1998. The study found that monetary influence is relatively stronger and more predictable than fiscal policy in determining economic activity in Zimbabwe. Onyeiwu (2012) examined the effect of monetary policy on the 
Nigerian economy using the Ordinary Least Squares Method to analyze data between 1981 and 2008. The results of the analysis showed that monetary policy represented by money supply exerts a positive impact on GDP growth and balance of payment. Furthermore, the findings of the study support the money-prices-output hypothesis for Nigerian economy. Amassoma (2011) examined the effect of monetary policy on macroeconomic variables in Nigeria for the period 1986 to 2009 by adopting a simplified Ordinary Least Squares technique and found that monetary policy had a significant effect on exchange rate and money supply while monetary policy was observed to have an insignificant influence on price instability. Adefeso and Mobolaji (2010) empirically examined the relative effectiveness of fiscal and monetary policies on economic growth in Nigeria using annual time series data spanning from 1970 to 2007. Error correction mechanism and co-integration technique were employed for the study. Gross domestic product, broad money, government expenditure and degree of openness were used as endogenous and exogenous variables. Empirical findings indicated that the effect of monetary policy on economic growth in Nigeria is much stronger than fiscal policy. The study recommended that policy makers should emphasize on monetary policy for the purpose of economic stabilization in Nigeria.

Jawaid et al. (2010) investigated the comparative effect of fiscal and monetary policy on economic growth in Pakistan using annual time series data from 1981 to 2009. The co-integration test conducted revealed the existence of long run relationship between monetary and fiscal policy with economic growth. However, monetary policy is found to be more effective than fiscal policy in enhancing the economic growth of Pakistan. The study recommended that policy makers should focus more on monetary policy than fiscal policy to ensure sustainable economic growth in Pakistan. Ali (2010) evaluated the monetary approach to the Pakistan balance of payments for the period 1990 to 2008 employing the reserve flow equation. The study tested whether excess money supply played a significant role as a disturbance by using co-integration test and error correction modeling. The empirical results showed that monetary variables do not play an overwhelming role in determining Pakistan's balance of payments. The study also revealed that balance of payments is not a purely monetary phenomenon. Therefore, equilibrium in the balance of payments cannot be corrected only through monetary actions by the authorities. Umer, et al., (2010) investigated the monetary approach to Pakistan's balance of payments for the period 1980 to 2008 using co-integration test and error correction modeling. The empirical results revealed that monetary variable does not play an overwhelming role in determining Pakistan's balance of payments and conclude that the balance of payments is not a purely monetary phenomenon. Chukuigwe and Abili (2008) examined econometric analysis of the impact of monetary and fiscal policies on Non-oil exports in Nigeria over the period 1974 to 2003. The study suggests that prudent and sustainable fiscal posture promotes "non inflationary economic growth, low and stable level of fiscal deficit and public debt, reduction of budget imbalances in situations of high fiscal deficit and public debt.

Ajisafe and Folorunso (2002) investigated the relative effectiveness of monetary and fiscal policies on economic activity in Nigeria over the period 1970 to 1998. Johansen co-integration test and error correction modeling technique were used for the study. Empirical findings revealed that monetary policy rather than fiscal policy exerts a great impact on economic activity in Nigeria. The study recommended that both monetary and fiscal policies should be complementary. Asogu (1998) empirically analyzed the relative potency of monetary and fiscal policies in Nigeria. The result of the estimate showed that coefficients of money supply were statistically significant while those of government expenditure were not significant. This agrees with the hypothesis that monetary actions are more potent than fiscal policy. Dhliwayo (1996) examined the monetary approach to Zimbabwe's balance of payments for the period 1980 to 1991 using multivariate cointegration and error correction modeling. The results showed that money played a significant role in determining the balance of payments and concluded that balance of payments disequilibrium can be corrected through appropriate financial programming and monetary targeting. Olaloye and Ikhide (1995) conducted a study on the role of fiscal and monetary policies in a depressed economy, a case study of Nigeria. Time series data spanning from 1986 to 1991 was used for the study. Empirical findings revealed that fiscal policy exerts more influence in the economy than monetary policy. The result, therefore, suggests that fiscal policy have been more effective in Nigeria at least in the point of depression.

\section{Description of Variables}


The dependent variable of the model which is to be influenced by a number of exogenous or explanatory variables is the balance of trade.

Balance of Trade- Balance of trade is the difference in the value of exports and imports of goods alone, that is, visible items. It is a major section of the balance of payment. Balance of trade of any given economy is influenced by numerous factors which include factor endowments, trade policies, exchange rates, inflation rates, foreign currency reserves, level of productivity and domestic demand. The net effect of balance of trade is either positive, negative or zero. A nation is said to have a favorable or surplus balance of trade if its exports value are greater than imports whereas an unfavorable or deficit balance of trade occurs when the values of imports are higher than exports. This dependent variable is expected to be influenced by numerous regressors which include money supply, government revenue, government expenditure, domestic debt, external debt, exchange rate, inflation rate and interest rate. The independent or exogenous variables included in the model which would determine the behavior of the endogenous variable are enumerated and elucidated below:

Money Supply- Money supply or money stock is the total value of monetary assets in an economy at a specific time. The circulating money involves currency, printed notes, money in the deposit accounts and in the form of other liquid assets. This variable theoretically is expected to exert positive influence on the balance of trade. An increase in money supply by the government through the monetary authority in an economy would translate to increased production of goods for domestic consumption and exportation, thereby creating positive linkage with balance of trade.

Government Expenditure- Government expenditure also known as government spending refers to the resources a government allocates to achieve its strategic objectives and satisfy the needs of the members of the nation. Governments spend money on health care, education, social security benefits, infrastructure and defense activities with a view to galvanizing the rate of economic growth. This variable is expected to be positively connected with the balance of trade. Increased expenditure by the government on security and critical infrastructures would encourage both domestic and foreign investors to invest massively in the production of exportable goods in the economy, thereby leading to positive improvement in the country's balance of trade. Government Revenue- Government revenue refers to the money received by a government from various sources in order to be able to cater for the needs of the citizens. The main sources of government revenue include tax, rates, fees, license fee, fine and penalties, gifts and grants, printing of paper money, surplus of the public sector unit and borrowings. This variable should have a positive correlation with the balance of trade. The higher the government revenue, the greater the volume of goods exported to foreign trading partners and vice versa. Domestic Debt- Domestic debt or internal debt refers to the money borrowed by the government of a country from its own citizens by selling bonds or long term credit instruments. Internal debt can also be described as that part of the total debt that is owed to lenders within the country. When government borrows from the domestic sources, the increase in inflation is less in comparison to simply printing the money. Commercial banks and other financial institutions constitute the sources of funds for internal debts. Theoretically, the variable is to exert a positive impact on the balance of trade.

External Debt- External debt alternatively known as foreign debt refers to that part of the total debt that is owed to creditors outside the country. The outside creditors can be foreign governments, international financial institutions such as World Bank, International Monetary Fund, Asian Development Bank, International Bank for Reconstruction and Development etc, corporate and foreign private households. External debt can be of several kinds such as multilateral, bilateral, IMF loans, trade credits, external commercial borrowings etc. when a country borrows externally, it has to pay interest on such debt along with the principal amount. This payment is to be made in foreign currencies or in gold. The variable is expected to have a positive relationship with balance of trade.

Exchange Rate- Exchange rate is the price of a nation's currency in terms of another currency. It is the price for which the currency of a country can be exchanged for another country's currency. Exchange rate is being influenced by several factors which include interest rate, inflation rate, trade balance, political stability, internal harmony, quality of governance, general state of the economy and high degree of transparency in the conduct of 
leaders and administrators. Nigeria's exchange rate of the naira has been experiencing persistent depreciation over the years. It is expected that this variable would be negatively related to balance of trade. Inflation Rate- Inflation is a sustained increase in the general price level of goods and services in an economy over a period of time. It can also be described as a quantitative measure of the rate at which the average price level of a basket of selected goods and services in an economy increases over a period of time. Often expressed as a percentage, inflation indicates a decrease in the purchasing power of a nation's currency. Nigeria's inflation rate has been increasing over the years. Theoretically, this variable is expected to influence balance of trade negatively.

Stochastic Variable- This variable takes care of other explanatory or exogenous variables influencing balance of trade which are excluded from the model. It represents the unexplained part of the model.

\section{Data and Methodology}

This study utilized data that are secondary in nature. The annual time series data was obtained from the various publications of the Central Bank of Nigeria Statistical Bulletin of various issues and National Bureau of Statistics. Empirical analysis was conducted on the basis of the sample spanning the period 1981 and 2017. The methods of analysis or estimation techniques include Augumented Dickey Fuller (ADF) unit root test, PhillipsPerron unit root test, Johansen cointegration test and Ordinary Least Squares (OLS) multiple regression method. Balance of trade (BOT) was used as the endogenous variable while money supply (MS), government revenue (GREV), government expenditure (GEXP), domestic debt (DDEBT), external debt (EDEBT), exchange rate (EXGR) and inflation rate (INFR) were used as exogenous or explanatory variables.

\section{Model Specification}

In this study, balance of trade (BOT) is made the endogenous variable while money supply (MS), government revenue (GREV), government expenditure (GEXP), domestic debt (DDEBT), external debt (EDEBT), exchange rate (EXGR) and inflation rate (INFR) are the exogenous or explanatory variables. This could be stated mathematically as:

$\mathrm{BOT}=\mathrm{F}(\mathrm{MS}, \mathrm{GREV}, \mathrm{GEXP}, \mathrm{DDEBT}, \mathrm{EDEBT}, \mathrm{EXGR}, \mathrm{INFR})$

where

BOT $=$ Balance of trade

MS = Monet supply

GREV $=$ Government revenue

GEXP $=$ Government expenditure

DDEBT $=$ Domestic debt

EDEBT $=$ External debt

$\mathrm{EXGR}=$ Exchange rate

$\mathrm{INFR}=$ Inflation rate

Introducing the constant term and the regression coefficients, we have the operational specification of the model as:

$\mathrm{BOT}=\mathrm{b}_{0}+\mathrm{b}_{1} \mathrm{MS}+$

$\mathrm{b}_{2} \mathrm{GREV}+\mathrm{b}_{3} \mathrm{GEXP}+\mathrm{b}_{4}$ DDEBT $+\mathrm{b}_{5}$ EDEBT $+\mathrm{b}_{6}$ EXGR $+\mathrm{b}_{7} \mathrm{INFR}+\mathrm{U}$

The apriori

expectations about the signs and magnitude of the variables are:

$\mathrm{b}_{1}, \mathrm{~b}_{2}$,

$b_{3}, b_{4}$ and $b_{5}>0: b_{6}$ and $b_{7}<0$

$b_{0}$ is the intercept or slope while $U$ is the stochastic error term.

\section{DATA OF ENDOGENOUS AND EXOGENOUS VARIABLES PRESENTED FOR ANAYSIS AND ESTIMATION}

\begin{tabular}{|l|l|l|l|l|l|l|l|l|}
\hline YEAR & $\begin{array}{c}\text { BOT } \\
\text { (\#billion) }\end{array}$ & $\begin{array}{c}\text { MS } \\
\text { (\#billion) }\end{array}$ & $\begin{array}{c}\text { GREV } \\
\text { (\#billion) }\end{array}$ & $\begin{array}{c}\text { GEXP } \\
\text { (\#billion) }\end{array}$ & $\begin{array}{c}\text { DDEBT } \\
\text { (\#billion) }\end{array}$ & $\begin{array}{c}\text { EDEBT } \\
\text { (\#billion) }\end{array}$ & $\begin{array}{c}\text { EXG } \\
\text { (\%) }\end{array}$ & $\begin{array}{l}\text { INFR } \\
\text { (\%) }\end{array}$ \\
\hline 1981 & -1.8 & 14.47 & 13.29 & 11.41 & 11.19 & 2.33 & 0.61 & 21.42 \\
\hline 1982 & -2.6 & 15.79 & 11.43 & 11.12 & 15.01 & 8.82 & 0.6729 & 7.16 \\
\hline
\end{tabular}




\begin{tabular}{|c|c|c|c|c|c|c|c|c|}
\hline 1983 & -1.4 & 17.69 & 10.51 & 9.64 & 22.22 & 10.58 & 0.7241 & 23.22 \\
\hline 1984 & 1.9 & 20.11 & 11.25 & 9.93 & 25.67 & 14.81 & 0.7649 & 40.71 \\
\hline 1985 & 4.7 & 22.30 & 15.05 & 13.04 & 27.95 & 17.3 & 0.8938 & 4.67 \\
\hline 1986 & 2.9 & 23.81 & 12.60 & 16.22 & 28.44 & 41.45 & 2.0206 & 5.39 \\
\hline 1987 & 12.5 & 27.57 & 25.38 & 22.02 & 36.79 & 100.79 & 4.0179 & 10.18 \\
\hline 1988 & 9.7 & 38.36 & 27.60 & 27.75 & 47.03 & 133.96 & 4.5367 & 56.04 \\
\hline 1989 & 27.1 & 45.9 & 53.87 & 41.03 & 47.05 & 240.39 & 7.3916 & 50.47 \\
\hline 1990 & 64.2 & 52.86 & 98.10 & 60.27 & 84.09 & 298.61 & 8.0378 & 7.5 \\
\hline 1991 & 32 & 75.4 & 100.99 & 66.58 & 116.2 & 328.45 & 9.9095 & 12.7 \\
\hline 1992 & 62.5 & 111.11 & 190.45 & 92.80 & 177.96 & 544.26 & 17.2984 & 44.81 \\
\hline 1993 & 53.1 & 165.34 & 192.77 & 191.23 & 273.84 & 633.14 & 22.0511 & 57.17 \\
\hline 1994 & 43.3 & 230.29 & 201.91 & 160.89 & 407.58 & 648.81 & 21.8861 & 57.03 \\
\hline 1995 & 195.5 & 289.09 & 459.99 & 248.77 & 477.73 & 716.87 & 21.8861 & 72.81 \\
\hline 1996 & 746.9 & 345.85 & 523.60 & 337.22 & 419.98 & 617.32 & 21.8861 & 29.29 \\
\hline 1997 & 395.9 & 413.28 & 582.81 & 428.22 & 501.75 & 595.93 & 21.8861 & 10.67 \\
\hline 1998 & -85.6 & 488.15 & 463.61 & 487.11 & 560.83 & 633.02 & 21.8861 & 7.86 \\
\hline 1999 & 326.5 & 628.95 & 949.19 & 947.69 & 794.81 & 2577.37 & 92.6934 & 6.62 \\
\hline 2000 & 960.7 & 878.46 & 1906.16 & 701.05 & 898.25 & 3097.38 & 102.1052 & $6 . .94$ \\
\hline 2001 & 509.8 & 1269.32 & 2231.60 & 1018.00 & 1016.97 & 3176.29 & 111.9433 & 18.87 \\
\hline 2002 & 231.5 & 1505.96 & 1731.54 & 1018.18 & 1166.00 & 3932.88 & 120.9702 & 12.89 \\
\hline 2003 & 1007.7 & 1952.92 & 2575.10 & 1225.99 & 1329.68 & 4478.33 & 129.3565 & 14.03 \\
\hline 2004 & 2615.7 & 2131.82 & 3920.50 & 1426.20 & 1370.33 & 4890.27 & 133.5004 & 15.01 \\
\hline 2005 & 4445.7 & 2637.91 & 5547.50 & 1822.10 & 1525.91 & 2695.07 & 132.147 & 17.35 \\
\hline 2006 & 4216.2 & 3797.91 & 8965.10 & 1938.00 & 1753.26 & 451.46 & 128.65 & 8.24 \\
\hline 2007 & 4397.8 & 5127.4 & 5727.51 & 2450.90 & 2169.64 & 438.89 & 125.83 & 5.38 \\
\hline 2008 & 4794.5 & 8008.2 & 7866.60 & 3240.82 & 2320.31 & 523.25 & 118.57 & 11.6 \\
\hline 2009 & 3125.7 & 10780.63 & 4844.59 & 3452.99 & 3228.03 & 590.44 & 148.88 & 12.4 \\
\hline 2010 & 3847.5 & 11525.53 & 7303.67 & 4194.58 & 4551.82 & 689.84 & 150.3 & 13.7 \\
\hline 2011 & 4240.8 & 13303.49 & 11116.85 & 4712.06 & 5622.84 & 896.85 & 153.86 & 10.8 \\
\hline 2012 & 5372.8 & 15483.85 & 10654.75 & 4605.39 & 6537.54 & 1026.9 & 157.5 & $12 . .08$ \\
\hline 2013 & 5822.6 & 15688.96 & 9759.79 & 5185.32 & 7118.98 & 1387.33 & 157.31 & 10.61 \\
\hline 2014 & 2421.7 & 18913.03 & 10068.85 & 4587.39 & 7904.03 & 1631.52 & 158.55 & 8.0 \\
\hline 2015 & -2230.9 & 20029.83 & 6912.50 & 4988.86 & 8837.00 & 2111.53 & 193.28 & 9.0 \\
\hline 2016 & -644.8 & 23591.73 & 5679.03 & 5160.74 & 11058.2 & 3478.92 & 253.49 & 15.7 \\
\hline 2017 & 3183.3 & 24140.63 & 7317.70 & 8302.10 & 12578.8 & 5787.51 & 305.7901 & 15.37 \\
\hline
\end{tabular}

Source: Central Bank of Nigeria Statistical Bulletin (2017) and National Bureau of Statistics

\section{Stationary Test}

It should be stated that if time series variables are non-stationary, all regression findings with these time series will be at variance from the conventional theory of regression with stationary series. That is, regression coefficients with non-stationary variables will be spurious and deceptive. To get over this problem, we test for stationarity of the time series. Conventional methods of Augumented Dickey Fuller unit root test and PhillipsPerron unit root test were used to investigate whether variables used in this study have a unit root or not. The results of the unit root tests are presented below 
AUGUMENTED DICKEY FULLER TEST STATISTICS OF THE VARIABES

\begin{tabular}{|l|l|l|l|l|c|c|}
\hline VARIABLES & $\begin{array}{c}\text { ADF } \\
\text { STATISTICS }\end{array}$ & $\begin{array}{l}\mathbf{1 \%} \\
\text { CRITICAL } \\
\text { VALUE }\end{array}$ & $\begin{array}{l}\text { 5\% } \\
\text { CRITICAL } \\
\text { VALUE }\end{array}$ & $\begin{array}{l}\text { 10\% } \\
\text { CRITICAL } \\
\text { VAUE }\end{array}$ & $\begin{array}{l}\text { ORDER OF } \\
\text { INTEGRATION }\end{array}$ & $\begin{array}{l}\text { MAX. } \\
\text { NO OF } \\
\text { LAG }\end{array}$ \\
\hline BOT & -3.729887 & -2.639210 & -1.951687 & -1.610579 & $\mathrm{I}(1)$ & 9 \\
\hline MS & -6.274037 & -3.711457 & -2.981038 & -2.629906 & $\mathrm{I}(1)$ & 9 \\
\hline GREV & -4.265506 & -2.650145 & -1.953381 & -1.609798 & $\mathrm{I}(1)$ & 9 \\
\hline GEXP & -4.633839 & -3.679322 & -2.967767 & -2.622989 & $\mathrm{I}(2)$ & 9 \\
\hline DDEBT & -6.978806 & -3.639407 & -2.951125 & -2.614300 & $\mathrm{I}(2)$ & 9 \\
\hline EDEBT & -5.656332 & -3.646342 & -2.954021 & -2.615817 & $\mathrm{I}(2)$ & 9 \\
\hline EXGR & -8.537160 & -3.639407 & -2.951125 & -2.614300 & $\mathrm{I}(1)$ & 9 \\
\hline INFR & -5.781653 & -3.632900 & -2.948404 & -2.612874 & $\mathrm{I}(1)$ & 9 \\
\hline
\end{tabular}

Source: Authors' Computation using E-view 9 version

PHILLIPS-PERRON TEST STATISTICS OF THE VARIABLES

\begin{tabular}{|l|l|l|l|l|c|c|}
\hline VARIABLES & $\begin{array}{c}\text { PP } \\
\text { STATISTICS }\end{array}$ & $\begin{array}{l}\text { 1\% } \\
\text { CRITICAL } \\
\text { VALUE }\end{array}$ & $\begin{array}{l}\text { 5\% } \\
\text { CRITICAL } \\
\text { VALUE }\end{array}$ & $\begin{array}{l}\text { 10\% } \\
\text { CRITICAL } \\
\text { VALUE }\end{array}$ & $\begin{array}{l}\text { ORDER OF } \\
\text { INTEGRATION }\end{array}$ & $\begin{array}{l}\text { MAX. } \\
\text { NO. OF } \\
\text { LAG }\end{array}$ \\
\hline BOT & -5.429931 & -3.670170 & -2.963972 & -2.621007 & $\mathrm{I}(2)$ & 3 \\
\hline MS & -6.337136 & -4.243644 & -3.544284 & -3.204699 & $\mathrm{I}(1)$ & 3 \\
\hline GREV & -5.949958 & -3.632900 & -2.948404 & -2.612874 & $\mathrm{I}(1)$ & 3 \\
\hline GEXP & -7.942597 & -2.634731 & -1.951000 & -1.610907 & $\mathrm{I}(2)$ & 3 \\
\hline DDEBT & -7.492476 & -3.639407 & -2.951125 & -2.614300 & $\mathrm{I}(2)$ & 3 \\
\hline EDEBT & -6.953989 & -3.639407 & -2.951125 & -2.614300 & $\mathrm{I}(2)$ & 3 \\
\hline EXGR & -9.810021 & -3.639407 & -2.951125 & -2.614300 & $\mathrm{I}(2)$ & 3 \\
\hline INFR & -8.783345 & -2.632688 & -1.950687 & -1.611059 & $\mathrm{I}(1)$ & 3 \\
\hline
\end{tabular}

Source: Authors' Computation using E-view 9 version

In tables 1 and 2 above, balance of trade (BOT), money supply (MS), government revenue (GREV), government expenditure (GEXP), domestic debt (DDEBT), external debt (EDEBT), exchange rate (EXGR) and inflation rate (INFR) are stationary at their various first and second differences.

\section{Johansen Co-integration Test}

Date: 01/21/19 Time: 12:09

Sample (adjusted): 19832017

Included observations: 32 after adjustments

Trend assumption: Linear deterministic trend

Series: BOT MS GREV GEXP DDEBT EDEBT EXGR INFR

Lags interval (in first differences): 1 to 1

Unrestricted Cointegration Rank Test (Trace)

\begin{tabular}{ccccc}
\hline \hline $\begin{array}{c}\text { Hypothesized } \\
\text { No. of CE(s) }\end{array}$ & Eigenvalue & $\begin{array}{c}\text { Trace } \\
\text { Statistic }\end{array}$ & $\begin{array}{c}0.05 \\
\text { Critical Value }\end{array}$ & Prob. ${ }^{* *}$ \\
\hline \hline None $*$ & 0.997219 & 599.0341 & 159.5297 & 0.0000 \\
At most 1 & 0.990203 & 410.7205 & 125.6154 & 0.0000 \\
At most 2* & 0.953290 & 262.7003 & 95.75366 & 0.0000 \\
At most 3* & 0.915722 & 164.6585 & 69.81889 & 0.0000 \\
At most 4 & 0.735178 & 85.50238 & 47.85613 & 0.0000 \\
At most 5 & 0.470544 & 42.98408 & 29.79707 & 0.0009 \\
At most 6* & 0.387235 & 22.63513 & 15.49471 & 0.0035 \\
At most 7* & 0.195532 & 6.962385 & 3.841466 & 0.0083 \\
\hline \hline
\end{tabular}

Trace test indicates 8 cointegrating eqn(s) at the 0.05 level 
* denotes rejection of the hypothesis at the 0.05 level

**MacKinnon-Haug-Michelis (1999) p-values

Unrestricted Cointegration Rank Test (Maximum Eigenvalue)

\begin{tabular}{ccccc}
\hline \hline $\begin{array}{c}\text { Hypothesized } \\
\text { No. of CE }(\mathrm{s})\end{array}$ & Eigenvalue & $\begin{array}{c}\text { Max-Eigen } \\
\text { Statistic }\end{array}$ & $\begin{array}{c}0.05 \\
\text { Critical Value }\end{array}$ & Prob. ${ }^{* *}$ \\
\hline \hline None $*$ & 0.997219 & 188.3136 & 52.36261 & 0.0001 \\
At most 1* & 0.990203 & 148.0202 & 46.23142 & 0.0000 \\
At most 2 & 0.953290 & 98.04178 & 40.07757 & 0.0000 \\
At most 3 & 0.915722 & 79.15616 & 33.87687 & 0.0000 \\
At most 4 & 0.735178 & 42.51831 & 27.58434 & 0.0003 \\
At most 5 & 0.470544 & 20.34894 & 21.13162 & 0.0640 \\
At most 6 & 0.387235 & 15.67275 & 14.26460 & 0.0298 \\
At most 7 & 0.195532 & 6.962385 & 3.841466 & 0.0083 \\
\hline \hline
\end{tabular}

Max-eigenvalue test indicates 5 cointegrating eqn(s) at the 0.05 level

$*$ denotes rejection of the hypothesis at the 0.05 level

**MacKinnon-Haug-Michelis (1999) p-values

Table 3 above shows the long run relationship existing among the variables of study. The table reveals that the variables converge in the long run thereby depicting the existence of long run relationship among them. The long run relationship exists at 5\% level of significance according to the Trace test statistics and the Maximum Eigenvalue test statistics. The trace test indicates 8 co-integrating equations while the Maximum Eigenvalue test shows 5 co-integrating equations. Consequent upon the existence of long run relationship among the variables in the study, the Ordinary Least Squares (OLS) estimating technique will be used to derive the long run impact of the independent variables ( MS, GREV, GEXP, DDEBT, EDEBT, EXGR, INFR) on the dependent variable (BOT).

Table 4

Dependent Variable: BOT

Method: Least Squares

Date: 01/21/19 Time: 12:02

Sample: 19812017

Included observations: 36

\begin{tabular}{crcrc}
\hline \hline Variable & Coefficient & Std. Error & t-Statistic & Prob. \\
\hline \hline C & -199.6449 & 305.3221 & -0.653883 & 0.5185 \\
MS & -0.506096 & 0.182777 & -2.768923 & 0.0099 \\
GREV & 0.461040 & 0.108964 & 4.231134 & 0.0002 \\
GEXP & 1.492799 & 0.382058 & 3.907256 & 0.0005 \\
DDEBT & -0.042285 & 0.398702 & -0.106057 & 0.9163 \\
EDEBT & -0.334085 & 0.226858 & -1.472664 & 0.1520 \\
EXGR & 6.381665 & 8.213261 & 0.776995 & 0.4437 \\
INFR & 3.449848 & 8.146458 & 0.423478 & 0.6752 \\
\hline \hline & 0.867639 & Mean dependent var & 1245.356 \\
R-squared & 0.834549 & S.D. dependent var & 1941.001 \\
Adjusted R-squared & 789.5156 & Akaike info criterion & 16.37385 \\
S.E. of regression & 17453375 & Schwarz criterion & 16.72574 \\
Sum squared resid & -286.7292 & Hannan-Quinn criter. & 16.49667 \\
Log likelihood & 26.22041 & Durbin-Watson stat & 1.994464 \\
F-statistic & 0.000000 & & & \\
Prob(F-statistic) & & & \\
\hline \hline
\end{tabular}


Table 5

Presentation of Regression Result

\begin{tabular}{|l|l|l|l|l|l|l|}
\hline VARIABLE & COEFFICIENT & $\begin{array}{l}\text { STANDARD } \\
\text { ERROR }\end{array}$ & $\begin{array}{c}\text { T- } \\
\text { STATISTIC }\end{array}$ & PROB. & $\begin{array}{l}\text { APRIORI } \\
\text { EXPECTATN }\end{array}$ & INFERENCE \\
\hline MS & -0.506096 & 0.182777 & -2.768923 & 0.0099 & $\mathrm{~b}_{1}>0$ & $\begin{array}{l}\text { Incorrect and } \\
\text { significant }\end{array}$ \\
\hline GREV & 0.461040 & 0.108964 & 4.231134 & 0.0002 & $\mathrm{~b}_{2}>0$ & $\begin{array}{l}\text { Correct and } \\
\text { significant }\end{array}$ \\
\hline GEXP & 1.492799 & 0.382058 & 3.907256 & 0.0005 & $\mathrm{~b}_{3}>0$ & $\begin{array}{l}\text { Correct and } \\
\text { significant }\end{array}$ \\
\hline DDEBT & -0.042285 & 0.398702 & -0.106057 & 0.9163 & $\mathrm{~b}_{4}>0$ & $\begin{array}{l}\text { Incorrect and } \\
\text { significant }\end{array}$ \\
\hline EDEBT & -0.334085 & 0.226858 & -1.472664 & 0.1520 & $\mathrm{~b}_{5}>0$ & $\begin{array}{l}\text { Incorrect and } \\
\text { significant }\end{array}$ \\
\hline EXGR & 6.381665 & 8.213261 & 0.776995 & 0.4437 & $\mathrm{~b}_{6}<0$ & $\begin{array}{l}\text { Incorrect and } \\
\text { significant }\end{array}$ \\
\hline INFR & 3.449848 & 8.146458 & 0.423478 & 0.6752 & $<0$ & $\mathrm{~b}_{7}$ \\
\hline $\begin{array}{l}\text { Significant } \\
\text { level 5\% }\end{array}$ & & & & $\begin{array}{l}\text { Incorrect and } \\
\text { significant }\end{array}$ \\
\hline
\end{tabular}

\section{Interpretation and Discussion of Empirical Findings}

Using the data from period 1981 to 2017 , we regressed and analyzed the prediction equation results of the model which was specified employing E-view 9 econometric software package to run the Ordinary Least Squares (OLS). From the results in table 5, it can be inferred that a unit increase in money supply (MS) on the average holding other explanatory variables constant will lead to 0.506096 unit decrease in balance of trade (BOT). This shows that money supply has a statistically significant negative impact on balance of trade within the studied period. This result negates apriori theoretical expectation. Empirical findings also revealed that a unit increase in government revenue (GREV) holding other exogenous variables constant will lead to 0.461040 unit increase in balance of trade (BOT). This shows that government revenue has a positive impact on balance of trade with the impact being statistically significant going by the low probability value. The result fulfils the apriori expectation. Also, a unit increase in government expenditure (GEXP) on the average holding other independent variables constant will lead to 1.492799 units increase in balance of trade. This implies that government expenditure has a statistically significant positive impact on balance of trade. This result is in conformity with apriori theoretical expectation.

The regression results also showed that domestic debt (DDEBT) and external debt (EDEBT) have inverse relationship with balance of trade. This is because a unit increase in domestic debt (DDEBT) and external debt (EDEBT) will lead to 0.042285 and 0.334085 units reduction in balance of trade respectively. Exchange rate (EXGR) and inflation rate (INFR) have statistically significant positive impact on balance of trade in Nigeria. A unit increase in exchange rate and inflation rate would bring about 6.381665 and 3.449848 units rise in balance of trade. This result negates the apriori theoretical expectation. The coefficient of determination R-squared shows that the model is a good fit with $0.867639(86 \%)$ change in balance of trade accounted for by the change in the independent variables. This implies that 86 percent of the variations in balance of trade in Nigeria was explained by changes in the explanatory variables. The unexplained variation of 14 percent could be attributed to some other variables influencing balance of trade which are not included in the model. The adjusted $\mathrm{R}^{2}$ is given as 0.834549 ( 83 percent). This means that precisely 83 percent of the variations in the balance of trade in Nigeria are accounted for by the included variables after the coefficient of determination $\left(\mathrm{R}^{2}\right)$ has been adjusted to make it insensitive to the number of included variables. The specification of the model is statistically significant given the F-test to be 26.22041. The F-statistic value of 26.22041 shows the overall significance of the model and this indicates that collectively, all the explanatory variables are important determinants of balance 
of trade in Nigeria. The Durbin-Watson statistics with a value of 1.994464 illustrates absence of autocorrelation among the variables in the model.

\section{Conclusion and Policy Recommendations}

Empirical findings from the study revealed that there exists a long run relationship among monetary and fiscal policies' instruments and balance of trade in Nigeria. This was confirmed by the positive relationship among government revenue, government expenditure, exchange rate and inflation rate while money supply, internal debt and external debt have inverse relationship with balance of trade. The negative relationship between money supply and balance of trade can be attributed to the non-utilization of the money received by individuals on productive ventures which has drastically reduced investment, lowered output and created balance of trade instability.

Based on the findings of this study, the following recommendations are advocated to enhance balance of trade stability in Nigeria:

-government at all levels should ensure implementation of monetary and fiscal policies' instruments aimed at promoting favorable investment atmosphere through appropriate stabilization of interest rates, exchange rates and inflation rates in order to galvanize economic growth, economic stability, economic sustainability and favorable balance of trade.

-there should be promotion of exportation of Nigerian products by the government especially non-oil products in order to bring more foreign exchange earning into the country, boost productive activities and improve the balance of trade position of the country.

-government should ensure that loans borrowed from domestic and external sources are judiciously expended on productive activities in order to positively influence balance of trade.

-there should be imposition of ban on importation of products that can be manufactured domestically so as to expand productive capacity of indigenous industries and ensure favorable balance of trade.

-Different tiers of government should invest massively on critical infrastructure in the economy to boost local investment in productive activities, thus galvanizing balance of trade.

-directive should be given to the central monetary authority by the government to ensure that the domestic money stock is consistent with the macroeconomic objectives of the country in order to experience favorable or surplus balance of trade position.

\section{References}

Adefeso, H. A. \& Mobolaji, H. I. (2010). The Fiscal-Monetary Policy and Economic Growth in Nigeria: Further Empirical Evidence. Pakistan Journal of Social Sciences, 7(2), 137-142.

Adegoriola, A. E. \& Siyan, P. (2015). The Relative Impact of Money Supply and Government Expenditure on Economic Growth in Nigeria. Economy, (S. I.), 2(3), 49-57.

Adewale, E. A. (2018). An Empirical Analysis of Effectiveness of Monetary and Fiscal Policy Instruments in Stabilizing Economy: Evidence from Nigeria. Social Sciences, 7(3), 133-140.

Ajayi, O. F. (2014). Determinants of Balance of Payments in Nigeria: A Partial Adjustment Analysis. Journal of African Macroeconomic Review, 5(1).

Ajisafe, R. A. \& Folorunso, B. A. (2002). The Relative Effectiveness of Fiscal and Monetary Policy in Macroeconomic Management in Nigeria. The African Economic and Business Review, 3(1), 23-40.

Ali, G. (2010). Pakistan's Balance of Payments as a Monetary Phenomenon: Econometric Evidence. Journal of Managerial Sciences, 5(2), 167-188.

Amassoma, D. (2011). An Appraisal of Monetary Policy and Its Effect on Macroeconomic Stabilization in Nigeria. Journal of Emerging Trends in Economics and Management Sciences, 2(3), 232-237.

Anna, G. (2012). The Relative Effectiveness of Monetary and Fiscal Policies on Economic Activity in Zimbabwe (1981-1998): An Error Correction Approach. International Journal of Management Sciences and Business Research, 1(5), 1-35.

Asogu, J. O. (1998). An Econometric Analysis of the Relative Potency of Monetary and Fiscal Policy in Nigeria, CBN Economic and Financial Review, 36(2), 30-63.

Boateng, C. \& Ayentimi, D. T. (2013). An Empirical Analysis of Balance of Payments in Ghana using the Monetary Approach. European Journal of Business and Management, 5(8), 101-110. 
Chigbu, E. E. \& Njoku, M. (2013). The Impact of Monetary and Fiscal Policies on Nigerian Economic Growth: 1990-2010. European Journal of Business and Management, 5(2).

Chukuigwe, E. C. \& Abili, I. D. (2008). An Econometric Analysis of the Impact of Monetary and Fiscal Policies on Non-Oil Exports in Nigeria (1974-2003). African Economic and Business Review, 6(2), 59-73.

Danjuma, B. F. (2013). An Empirical Analysis of the Balance of Payments as a Monetary Phenomenon: Nigeria's Experience. Journal of Emerging Issues in Economics, Finance and Banking (JEIEFB), 1(2), 107-128. Dhilwayo, R. (1996). The Balance of Payments as a Monetary Phenomenon: An Econometric Study of Zimbabwe's Experience. African Economic Research Consortium Research Paper 46, Nairobi, March 1996. Falade, O. E. \& Folorunso, B. A. (2015). Fiscal and Monetary Policy Instruments and Economic Growth Sustainability in Nigeria. American Journal of Economics, 5(6), 587-594.

Havi, E. D. \& Enu, P. (2014). The Effect of Fiscal Policy and Monetary Policy on Ghana's Economic Growth: Which Policy is More Potent? International Journal of Empirical Research, 3(2), 61-75.

Imosi, A. I., Olatunji, L. M. \& Ekpenyong, B. I. (2013). Monetary Policy and its Implications for Balance of Payments Stability in Nigeria: 1980-2010. International Journal of Economics and Finance, 5(3), 196-204. Imoughele, L. E. \& Ismaila, M. (2015). Monetary Policy and Balance of Payments Stability in Nigeria (19862013). International Journal of Academic Research in Public Policy and Governance, 2(1), 1-15.

Iyeli, I. I., Uda, E. B. \& Akpan, E. (2012). The Relative Effectiveness of Monetary and Fiscal Policies in Economic Stabilization in a Developing Economy: An Empirical Evidence from Nigeria. African Journal Online, 3(1).

Jawaid, S. T., Arif, I. \& Naeemullah, S. M. (2010). Comparative Analysis of Monetary and Fiscal Policy: A Case Study of Pakistan. NICE Research Journal, 3, 58-67.

Kareem, R. O., Afolabi, A. J., Raheemand, K. A. \& Bashir, N. O. (2013). Analysis of Fiscal and Monetary Policies on Economic Growth: Evidence from Nigerian Democracy. Current Research Journal of Economic Theory, 5(1), 11-19.

Ogar, A., Nkamare, S. E. \& Emori, E. G. (2014). Fiscal and Monetary Policy and its Effect on the Growth of Nigerian Economy. European Journal of Business and Management. 6(29).

Olaoye, A. O. \& Ikhide, S. I. (1995). Economic Sustainability and the Role of Fiscal and Monetary Policies in a Depressed Economy: The Case Study of Nigeria. Sustainable Development, 3, 89-100.

Onyeiwu, C. (2012). Monetary Policy and Economic Growth of Nigeria. Journal of Economics and Sustainable Development, 3(7), 62-71.

Tijani, J. O. (2013). Empirical Analysis of Balance of Payment Adjustment Mechanisms: Monetary Channel in Nigeria (1970-2010). Mediterranean Journal of Social Sciences, 5(14), 67-76.

Umer, M., Muhammad, S. D., Abro, A. A., Sheikh, Q. A. \& Ghazali, A. (2010). The Balance of Payments as a Monetary Phenomenon: Econometric Evidence from Pakistan (http://www.eurojournals.com/finance.htm) 